생명과학분야의 분야별 연구인력 및 연구성과 분석 민태선* · 김성용** . 박수현*** · 한인규****

한국과학재단 전문위원실*, 한국지질자원연구원 정책연구부**, 전남대학교 수의과대학***, 서울대학교 농업생명과학대학****

\title{
A Comparison Study on Characteristics of Research Output in Life Sciences and Other Sciences Through Analysis of KOSEF's Database
}

\author{
Tae-Sun Min*, Seong-Yong Kim**, Soo-Hyun Park*** and In-Kyu Han****
}

Korea Science and Engineering Foundation (KOSEF)*, Korea Institute of Geoscience and Mineral Resources (KIGAM)**, College of Veterinary Medicine, Chonnam National University***, College of Agriculture and Life Sciences, Seoul National University****

\begin{abstract}
Research outputs of science and engineering fields including Life Sciences were analyzed using KOSEF's Database. The total number of Life Sciences scientists participating in KOSEF's Database was 7,413(33.1 percent), and during the latest five years(2001 to 2005), the number of articles published in SCI(Scientific Citation Index) journals and Non-SCI journals by them was 47,740(37.7 percent) and 72,115(39.9 percent), respectively. The average number of articles per capita published in SCI journals during the latest five years was 5.0 in Biology, 4.1 in Agricultural Sciences, and 7.5 in Medical Sciences. The average number of articles per capita published in SCI journals within Life Sciences was 12.1 in Pharmaceutical Chemistry, 10.3 in Allergy and Immunology, 10.0 in Physiology and Pharmacology, 9.7 in Anatomy and Cell Biology, in order. The results of this survey will be used as a reference in comparisons of research output between Life Sciences and other sciences both in quality and quantity.
\end{abstract}

(Key words : Research output, Life Sciences, KOSEF's Database).

\section{I. 서 론}

전 세계적으로 한정된 국가자원 속에서 연구개 발투자가 점차적으로 증가하고 프로그램들이 다 양화되자 정부가 추진하고 있는 연구개발프로그 램들의 책무성과 효과성을 제고해야 한다는 목소 리가 점차 높아져 왔다. 이에 따라 각국 정부는 예산집행의 효과성과 효율성, 투명성 그리고 정부 지원의 타당성을 확보하기 위해 사업에 대한 성 과평가 제도를 도입하고, 국가 연구개발 활동에 대한 종합조정을 강화시켜 오고 있다. 우리나라에 서도 1990년대 이후 연구개발투자가 급격히 증가 하고, 추진주체가 다양화되자 기초연구투자의 효 율성을 높이기 위한 시도가 활발히 이루어지고 있으며, 성과에 대한 관심이 정책결정권자와 연구
자 둘 모두에게 고조되고 있다.

그러나 분야별 연구의 특성이 다르고 이의 성 과형태 및 특성이 다양하기 때문에 경우에 따라 서는 서로 간에 성과물의 수치를 상대적으로 비 교하기에는 한계가 있는 실정이며 성과에 대한 부분을 객관화 시키는 부분에 있어서 별다른 대 안을 찾지 못하고 있다. 특히, 기초연구는 특성상 성과지표(performance indicator)가 모호하고 비가 시적이며 장기적인 특성이 있으므로 활용방안이 나 기대효과, 산업에 미치는 영향 등에 대한 단 기적 산출(output)을 기대하는 것은 더욱 어려운 실정이다. 그러나 대학의 연구가 기초연구 중심 이고 그 연구성과를 단순한 논문편수 중심의 정 량적인 형태로는 측정하기 어렵다고 하더라도 정량 및 정성적인 평가를 정확하게 할 수 있는

Corresponding author : Tae-Sun Min, 180-1 Kajeong-dong, Yuseong-gu, Daejeon 305-350, Korea Tel. 82-42-869-6531, E-mail : tsmin@kosef.re.kr 
성과지표를 개발하여 이를 활용한 선진투자기법 의 연구지원 방향이 확립되어야 하는 데 딜레마 가 있다.

기초연구 또는 기반연구의 성과는 학술적 성과, 교육훈련 성과, 기술적 성과 등으로 나눌 수 있으 며, 학술적 성과는 전문학술지 논문게재, 학술대회 논문발표 등이고, 교육훈련 성과는 Post-Doc. 연수, 박사 학위자 배출, 석사 학위자 배출로 나눌 수 있 으며, 기술적 성과는 특허출원 및 등록, 기술지도 및 기술제공, 실용화 응용지원 등이 포함된다고 할 수 있다. 그러나 이러한 성과를 분야간에 정량 적으로 비교 분석할 때 제일 큰 한계는 분야별 특 성을 감안하는 척도가 부족하다는 것이다. 분야에 따라서는 연구 성격상 논문 등의 산출물 생산이 용이하거나 그렇지 못할 경우도 있기 때문에 서로 다른 분야를 동일선상에서 고찰하는 것을 보완하 는 방안이 필요한 것이다. 이에 따라 본 연구에서 는 최근 5 년간의 과학재단의 연구인력 데이터베이 스 자료(한국과학재단, 2005a)를 분석하고 이를 근 거로 하여 분야별 연구인력 및 연구실적으로 비교 하여 연구분야별 특성을 파악하고자 한다.

한국과학재단(2005b)의 분석에 따르면 최근 5년 간(1999-2003) SCI 논문을 가장 많이 발표한 분야 는 응용물리학/고체물리/재료과학이며, 분야별 총 합논문수(87,946건) 중 논문수 상위 10 개 분야가 차지하는 비율은 $48.23 \%$ 로 조사되었다. 그러나 이 러한 분야별 논문수의 점유율 비교 분석은 우리 나라 연구자의 양적 규모 등의 변수를 감안하지 않았다는 단점이 있다고 할 수 있다.

기초과학 및 기초연구분야로서 생명과학은 인 류의 역사와 더불어 시작된 농업 및 수산업을 발 전시키기 위한 기초지식 및 응용기술의 개발을 목표로 생명체와 자연을 대상으로 연구하는 농수 산학(Agricultural Sciences), 지구생태 및 진화, 미 생물 및 기생생물, 식물 및 동물 등의 분야를 대 상으로 연구하는 생물학(Biology), 그리고 질병의 원인규명을 통한 질병의 직접적인 이해와 치료제 등을 연구하는 기초의과학(Medical Sciences) 등이 포함된다(민 등, 2005). 따라서, 본 연구에서는 생 명과학을 과학재단의 분야분류상에 기초하여 중 분야 분류를 농수산학, 생물학 및 기초의과학으로 나누었으며 좀더 구체적으로 살펴보면 생물공학, 식품과학, 농림학, 축산수의과학, 수산학을 농수산 학으로, 생태 및 진화학, 미생물 및 기생생물, 식물
학, 동물학을 생물학으로, 해부 및 세포생물학, 노 화 및 종양학, 생화학 및 분자생물학, 유전학, 면역 학, 신경과학, 임상의과학, 생리 및 약리학, 임상기 술 및 방법론, 약품화학, 생약학, 약제학, 위생약 학, 공중보건 및 안전분야를 기초의과학으로 분류 하여 Database화 시켰다.

\section{ㅍ. 이공계 연구인력 분포 및 연구실적 비교}

우리나라 이공계 분야에서 활동 중인 연구자중 2005년 8월 현재 한국과학재단의 연구인력 $\mathrm{DB}$ 에 는 22,378명의 연구분야분류가 가능한 연구자들의 연구실적 관련정보가 구축되어 있고, 동 $\mathrm{DB}$ 는 연 구자가 수시로 실적을 갱신하는 시스템이며 최근 에는 학술진흥재단과 업무협력으로 $\mathrm{DB}$ 를 통합하 여 운영하고 있다. 본 연구에서는 이 과학재단 $\mathrm{DB}$ 를 근거로 하여 최근 5년간(2001 2005)의 연 구실적을 분석하였다. 단, 논문 공저로 인한 논문 수 중복계상은 인정하였다.

최근 5 년간 이공계 분야에서 학술지에 게재된 논문은 국내 일반 학술지 151,686편, 국내 SCI 학 술지 10,064편으로 국내 학술지 전체가 161,750 편이며, 국외 일반 학술지 28,978편, 국외 SCI 학 술지 116,481편으로 국외 학술지 전체 145,459편 이었으며, 국내외 SCI 학술지는 126,545 편이고, 국내외 일반학술지는 180,664 편으로서 국내외 학 술지 게재논문 전체는 307,209편으로 조사되었 다. 그리고 국내 학술대회발표논문은 144,198편, 국외 학술대회발표논문은 81,281 편으로서 학술 지 게재와 학술대회 발표를 포함한 최근 5년간 국내 이공계분야의 전체 연구실적은 532,688편으 로 나타났다.

그 중 생명과학분야의 연구인력은 7,413명(점유 율 33.1\%)으로서 국내 학술지 게재논문수는 일반 학술지 게재 62,623편, 국내 SCI 게재 4,116편으로 국내 학술지 게재 총논문수는 66,739편(점유율 $41.0 \%$ )이었으며, 국외학술지 게재 논문수는 일반 학술지 게재 9,492편, 국외 SCI 게재 43,624편으로 국외 학술지 게재 총 논문수는 53,116편(점유율 $36.5 \%$ )이었다. 국내외 학술지를 합한 일반 학술지 는 72,115편(점유율 39.9\%), SCI 학술지는 47,740 편(점유율 37.7\%)이고 학술대회 발표논문을 포함 한 생명과학분야 전체의 연구실적은 173,066 편으 
로 국내 이공계분야에서의 점유율이 $32.5 \%$ 로 나 타났다. 기초의과학분야의 연구자 수 $(4,794$ 명, 전 체의 21.4\%)가 생명과학분야내 생물분야(975명, 4.4\%)나 농수산분야(1,644명, 7.4\%) 등에 비해 두 드러지게 높았으며 이것은 분야별 전체 연구실적 (기초의과학분야 115,484 편, $21.7 \%$; 생물분야 18,969 편, $3.6 \%$; 농수산분야 38,613편, $7.3 \%$ )과 비슷한 경향을 나타내었다. 농수산분야의 경우 일반 학술 지 게재점유율이 두드러지게 높게 나타났다.

타 분야의 전체 연구실적을 보면, 수학, 컴퓨터 과학, 토목 • 건축공학분야는 연구인력 점유율에 비 해 전체 논문수 점유율이 낮았으며, 재료과학 및 화학공학 분야는 연구인력 점유율에 비해 전체 논 문 수 점유율이 두드러지게 높은 것으로 나타났다.

최근 5 년간 이공계분야 전체의 1 인당 평균 논 문실적은 국내 일반학술지 6.8편, 국내 SCI 학술 지 0.4편, 국외 일반학술지 1.3 편, 국외 SCI 학술지 5.2 편으로 1 인당 평균 SCI 학술지 5.6편, 일반학술 지 8.1편으로 분석되었다. 생명과학분야의 경우 최근 5 년간 1 인당 논문실적은 국내 학술지는 국 내 일반학술지 8.4편, 국내 SCI 학술지 0.6편으로 전체 9.0편이고, 국외 학술지는 국외 일반학술지 1.3 편, 국외 SCI 학술지 5.9편으로 전체 7.2편으로 서 SCI 학술지 전체는 6.4편, 일반학술지 전체는 9.7편으로 분석되었다. 1 인당 평균 학술대회 논문 발표도 국내 학술대회는 4.7편, 국외 학술대회는 2.5편으로 전체 7.2편이었으며, 이를 근거로 할 때 생명과학분야의 최근 5 년간 1 인당 평균 연구실적 은 23.4편으로 나타났다. 최근 5년간 1 인당 평균 연구실적을 기초의과학, 농수산, 생물로 구분하여 살펴볼 때, 일반학술지 전체는 농수산(10.5편), 기 초의과학(9.9편), 생물(7.7편) 순이었으며 SCI 학술 지 전체는 기초의과학(7.5편), 생물(5.0편), 농수산 (4.1편) 순으로 농수산분야 연구자들의 SCI 학술 지 발표가 적었는데, 이는 타분야에 비해 논문을 게재할 SCI 학술지가 상대적으로 적었기 때문인 것으로 사료된다. 5 년간 1 인당 평균연구실적은 기 초의과학(24.1편), 농수산(23.5편), 생물(19.5편) 순 으로 나타났다. 한편 최근 5년간 과학재단의 지원 에 의해 게재된 SCI 논문의 중분야별 분포현황을 살펴본 자료에 의하면(과학재단, 2004), 전분야대 비 동식물학은 $2.5 \%$, 농학은 $0.3 \%$ 에 그치고 있으 며, 대분야별로 살펴 보았을 때에도 농업, 생물\& 환경과학분야는 전분야의 $3.9 \%$ 에 그치고 있다.
타 이공계 분야와 비교하여 보면, 최근 5 년간 1 인당 SCI 학술지 게재실적은 수학 3.9편, 물리학 13.4 편, 화학 11.3 편, 지구과학 2.9편, 재료과학 10.8 편, 기계공학 3.9 편, 전자공학 4.4편, 컴퓨터과 학 2.4편, 토목 - 건축공학 1.0 편, 화학공학 6.9 편, 융합과학 2.5 편으로서 분야별로 차이를 나타내고 있다. 따라서 모든 분야가 동일한 연구능력 및 환 경조건이라 가정하였을 때 예컨대, 생물분야의 SCI 학술지 게재논문 1 편은 물리학의 2.7 편, 기초의과 학의 1.5 편으로, 농수산분야의 SCI 학술지 게재논 문 1 편은 물리학의 3.3 편, 생물학의 1.2 편, 기초의 과학의 1.8 편에 해당한다고 할 수 있다. 그러나 분 야간 논문실적의 객관적인 상대적 비교가 가능하 게 하려면 분야간 형평성을 감안한 합리적인 조 정지수의 개발 등이 필요하다. 그리고 공저자수, 논문 공저자별 편당 기여도 및 SCI 학술지 피인용 회수가 절대적으로 반영되는 영향력지수 (Impact Factor) 등도 반영되어야 할 것이다(Table 1).

\section{III. 생명과학 세부분야별 연구인력 분포 및 연구실적 비교}

생명과학분야의 과학재단 인력 $\mathrm{DB}$ 에 수록된 인원은 7,413명이었다. 농수산(1,644명, 생명과학 분야의 $22.2 \%$ <이하 “생명과학분야내 점유율”>) 분야 중에서는 식품과학(622명, 8.4\%)과 농림학 (429명, 5.8\%)분야가, 생물학(975명, 13.2\%) 분야 에서는 미생물 및 기생생물(428명, 5.8\%) 분야가 타세부분야에 비해 높은 점유율을 보였다. 또한 기초의과학(4,794명, $64.7 \%)$ 분야에서는 임상의 과학(948명, $12.8 \%)$, 생화학 및 분자생물학(887명, $12.0 \%)$, 신경과학(460명, $6.2 \%)$, 노화 및 종양학 (406명, 5.5\%) 순으로 연구자가 많았다.

과학재단 연구분야 분류기준에 따라 본 연구에 서는 연구인력 및 연구실적 등을 생물학 4 개분 야, 기초의과학 14 개분야, 농수산 5 개분야로 제 시하였다. 최근 5 년간 논문실적으로 보면, 국내 학 술지 게재논문은 임상의과학 12,958편(19.4\%), 식 품과학 6,654편(10.0\%), 임상기술 및 방법론 4,880 편(7.3\%), 생화학 및 분자생물학 4,269편(6.4\%), 농림학 4,149편(6.2\%), 노화 및 종양학 4.099편 (6.1\%) 순이었다. SCI 학술지 게재논문은 생화학 및 분자생물학 8,070편(16.9\%), 임상의과학 5,151 편(10.8\%), 신경과학 4,095편(8.6\%), 해부 및 세포 
Min et al. ; Characteristics of Research Output in Life Sciences 
Min et al. ; Characteristics of Research Output in Life Sciences

- 135 - 
생물학 3,436편(7.2\%), 노화 및 종양학 3,144편 (6.6\%) 순으로 나타났다. 국내외 학술지 논문게 재 및 학술대회 논문발표 전체실적의 점유율을 보면 임상의과학(14.7\%), 생화학 및 분자생물학 (10.3\%), 식품과학(9.0\%), 면역학(7.3\%) 순으로 분석되었다. 한편 축산 및 수의과학은 연구자 수 는 202명으로 $2.7 \%$ 의 점유율을 나타내었고, 국 내학술지 게재논문은 2,207 편으로 $3.3 \%, \mathrm{SCI}$ 학 술지 게재논문은 1,262 편으로 $2.6 \%$, 국내외 학술 지 논문게재 및 학술대회 논문발표 전체실적은 5,063 편으로 $2.9 \%$ 의 점유율을 보였다.

생명과학분야의 최근 5 년간 1 인당 평균 논문실 적으로 보면, 국내학술지 게재논문수는 임상기술 및 방법론 14.2편, 임상의과학 13.7편, 생약학 12.6 편, 수산학 11.1편 순이며, SCI 학술지 게재논문수 는 약품화학 12.1편, 면역학 10.3편, 생리 및 약리 학 10.0편, 해부 및 세포생물학 9.7편 순으로 나타 났으며, 논문게재 및 학술발표를 포함한 1 인당 평 균 연구실적은 생리 및 약리학 28.6편, 생약학 27.7편, 신경과학 27.6편, 임상의과학 26.8편 순으 로 나타났다. 축산 및 수의과학의 경우는 1 인당 국내학술지 게재논문수는 10.9 편, SCI 학술지 게 재논문수는 6.2편으로 나타났고, 논문게재 및 학 술발표를 포함한 1 인당 평균 연구실적은 25.1편으 로 전분야 평균(23.8편) 및 생명과학분야 평균 (23.7편)에 비해 높은 수치를 나타내었다(Table 2).

\section{IV. 결론 및 시사점}

본 연구에서는 최근 5년간 생산된 논문실적을 기준으로 하여 모든 분야가 동일한 연구능력 및 환경을 갖는다고 가정 할 때, 생물분야의 SCI 학 술지 게재논문 1 편은 물리학의 2.7 편, 기초의과 학의 1.5 편으로, 농수산분야의 SCI 학술지 게재 논문 1 편은 물리학의 3.3 편, 생물학의 1.2 편, 기 초의과학의 1.8 편에 해당한다고 가정하는 방향 을 제시하고자 하였다. 그리고 이러한 가정은 기 존에 시도되지 않은 분야간의 연구실적의 양적 형평성의 비교를 위한 근거 자료로 활용될 수 있는 시도이다. 아울러, 질적인 비교의 수준으로 활용되고 있는 국제저명학술지(SCI)의 피인용 회수가 절대적으로 반영되는 영향력지수(Impact Factor)와 더불어 이공계 분야간의 양적 비교를 겸할 수 있는 측면에서 적절히 활용이 될 수 있
을 것으로 여겨진다. 모두가 공감할 수 있는 분 야간 형평성을 감안한 종합 조정지수 개발을 위 해서는 이공계 전분야의 관련 전문가가 대규모 로 참여하여 세부분야별 연구자들의 생애기간동 안의 국내외 논문게재실적(국내전문학술지, SCI 급 학술지 등) 및 지적재산권 실적 등의 비교를 실시하고 연령별, 성별, 지역별, 대학별 비교를 실시하는 것이 필요하다. 이러한 심층비교 분석 을 토대로 이공계 분야간 합리적이고 공감할 수 있는 연구개발실적 및 성과 조정지수를 개발하 고 제안할 수 있을 것으로 사료된다.

$$
\text { V. 요 약 }
$$

한국과학재단 연구인력 $\mathrm{DB}$ 를 활용하여 생명 과학을 포함한 국내 이공계 연구자의 연구실적 특성을 분석하였다. $\mathrm{DB}$ 에 수록된 생명과학분야 연구자수는 7,413명(점유율 33.1\%)으로서 최근 5 년간(2001년부터 2005년까지) 게재실적은 SCI 학 술지가 47,740편(점유율 37.7\%)이었고, 일반학술 지가 72,115편(점유율 39.9\%)이었다. 최근 5년간 1 인당 SCI 학술지 게재실적은 생물 5.0편, 농수 산 4.1편, 기초의과학 7.5편으로 조사되었다.

생명과학분야중 세부분야별 연구자의 1 인당 SCI 논문게재 실적은 약품화학 12.1편, 면역학 10.3편, 생리 및 약리학 10.0편, 해부 및 세포생물 학 9.7편 순이었다. 본 조사분석 연구결과는 생명 과학 세부분야간 또는 타 이공계 분야간의 연구 실적의 양과 질적인 측면에서의 상대 비교를 위 한 근거로 활용될 수 있을 것으로 사료된다.

\section{VI. 인 용 문 헌}

1. 민태선, 김성용, 조순영, 정순욱, 한인규. 2005. 한국과학재단의 생명과학분야 기초연구지원 추이분석을 통한 연구활동 활성화 제언. 한국 생명과학회지. 15(1):152-159.

2. 한국과학재단. 2004. 과학재단 연구과제의 질 적 수준 분석. pp. 14-16.

3. 한국과학재단. 2005a. 연구인력 data base.

4. 한국과학재단. 2005b. SCI DB를 이용한 국내 대학 연구실적의 지표 시스템 개발 및 질적 수준 분석. p. 53.

(접수일자 : 2005. 8. 23. / 채택일자 : 2006. 2. 15.) 